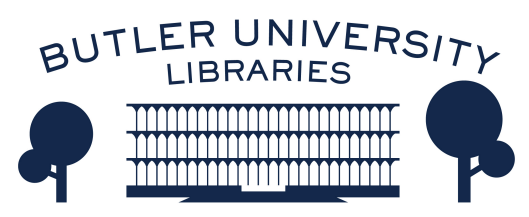

Journal of Hindu-Christian Studies

Volume 25

Article 21

November 2012

\title{
Book Review: "Brahman and Person: Essays by Richard De Smet"
}

Bradley Malkovsky

Follow this and additional works at: https://digitalcommons.butler.edu/jhcs

Part of the Religion Commons

\section{Recommended Citation}

Malkovsky, Bradley (2012) "Book Review: "Brahman and Person: Essays by Richard De Smet"," Journal of Hindu-Christian Studies: Vol. 25, Article 21.

Available at: https://doi.org/10.7825/2164-6279.1527

The Journal of Hindu-Christian Studies is a publication of the Society for Hindu-Christian Studies. The digital version is made available by Digital Commons @ Butler University. For questions about the Journal or the Society, please contact cbauman@butler.edu. For more information about Digital Commons @ Butler University, please contact digitalscholarship@butler.edu. 


\section{Brahman and Person: Essays by Richard De Smet. Edited with introduction by Ivo Coelho. Delhi: Motilal Banarsidass, 2010, 294 pp.}

RICHARD De Smet (1916-1997) was a Belgian Jesuit priest and professor of Indian thought who spent almost his entire professional life in India at the Catholic faculty of Jnana-Deepa Vidyapeeth in Pune. He is widely regarded as one of the greatest Christian philosophers and indologists living in India in the twentieth century. His contributions to Hindu-Christian metaphysical comparison were wide-ranging and deep, and, though his writings are little known in the West, they continue to exert considerable influence on Christian philosophers and theologians working in India who are wrestling with the meaning and significance of Hindu systematic thought for Christian theology. I consider myself fortunate to have spent numerous conversations with Father Richard in his little room at the Jesuit seminary in Pune when I was first discovering Vedānta, during which time he corrected and refined my clumsy attempts at grasping the subtlety of Śankara's thought.

Although De Smet's expertise was in Śankkara-Vedānta he was well aware that his was a minority interpretation among scholars of Advaita. The great majority of Śankara's interpreters, whether Hindu or Christian, see the great ācārya as espousing an ontology which De Smet called "acosmic illusionism," as well as a theology that rejected the notion that the supreme brahman, i.e. the para brahman, was in any sense personal. De Smet was opposed to both these renderings of Śankara's teaching. He argued, in accord with the exegetical method applied to Śankara's writings by Paul Hacker and against Advaita tradition, that the best way to grasp the authentic teaching of Śankara was to bypass the Advaita commentaries on the ācarrya and return to the master himself to see what he taught. There you will find, says De Smet, Śankara's very subtle teaching on a real creation as well as the affirmation of real personhood in the para brahman. The obvious question here is whether De Smet was - knowingly or unknowingly - projecting his own Christian doctrinal beliefs and convictions onto Śankkara's writings. But even a traditional Śankara scholar with the authority of T. M. P. Mahadevan eventually came to profess the personhood of the supreme brahman in opposition to his earlier convictions, and he did this under the influence of De Smet's participation in national congresses of Indian philosophy.

The editor of this volume, Ivo Coelho, who is a Salesian priest and philosophy professor in Nashik and Jerusalem, was a student and friend of De smet for many years. He is also the foremost authority on De Smet's work today. The present volume is a labor of love, posthumously honoring a teacher by bringing together fourteen of De Smet's most important essays on the topic of person, articles in which he reflects on both human and divine personhood, as they are articulated in both Indian and Western contexts. Coelho's eighteen page introductory essay, which is divided into sections on "Divine Personality," "Human Personality," and "Dialogue and Theology," provides a very helpful summary of the book's contents. This is important, as De Smet's essays were written in a style characterized not only by remarkable precision, but also by an extraordinary density and an extreme economy of expression, so that one must ponder them slowly, sometimes reading them many times over in order to grasp their full import.

The articles gathered in this book are ordered according to their chronological publication, starting in 1957 and ending in 1996. Some of the material therefore overlaps from one essay to the other, as De Smet builds on and develops his earlier insights. His intended audience is sometimes Hindu, at other times Christian. Despite the various themes covered in the book there are two main contributions De Smet makes to the topic of person that remain visible throughout, according to Coelho. They are 1. his teaching 
on the personhood of Śankkara's para brahman and 2. his working out of "an Indian view of the [human] person and even an Indian humanism." (10)

De Smet works both historically and systematically, tracing developments in India, from the Vedas and early Buddhism up to modern Indian thought, and in the West, starting with Christian theology and then tracing the development of the concept of person in Western philosophy as it gradually divorces itself from its Christian theological moorings. It is because of the loss of a holistic understanding of person and its reduction in the West to the human individual's subjective and limited consciousness ("atomic individualism") that the concept became more difficult to apply to the Divine in any proper way. The result, writes De smet, was detrimental for cross-cultural studies. Western indologists, especially the Germans, in their translation of Sanskrit texts, began to apply the modern impoverished understanding of person to the saguna brahman, thereby relegating any notion of a personal God to an inferior position in theology. And because Christians used the same term, "person," for God, it was understandable that many Hindus, especially Advaitins, would understand the christian conception of an ultimate reality to be a limited anthropomorphic conception. And so one of the purposes of De Smet's essays on person was to make clear how the notion of person, when understood properly, can apply to the Absolute without entailing the loss of Its transcendence, independence and simplicity. This proper understanding of the Divine is what he called the "retrieval of the person."

Though there is no term in Indian languages that corresponds exactly to "person"
De smet came to realize, against his earlier position, that the Indian religions do contain much material for an authentic humanism, both in the bodhisattva ideal of Buddhists and in the rise of Hindu bhakti movements with their practice of selfless compassion which emulates the selfless love and grace of God.

The greatest obstacle in India to the holistic concept of human person, adds De Smet, one that would embrace the dignity of the human person in their entirety as both body and soul, is the doctrine of reincarnation, which, at least on the popular level of understanding, is clearly dualistic, as the body here in no way can belong to the human individual's true identity.

It was one of the more noteworthy features of De Smet's development as a Christian student of Indian thought that he eventually came to recognize a greater convergence of Indian and Western values over the long course of history than he did during his early years in India. De Smet therefore serves as a model of what good comparative work should be, one that involves a readiness to grow in insight and to revise one's original convictions while remaining faithful to the best of one's home tradition.

At the end of the book Coelho has provided a forty-four page bibliography of De Smet's writings (757 entries!) and three pages more of the most important essays on De Smet by his admirers and critics. Those who are interested in comparative systematic studies will be grateful for this valuable work. It serves to deepen our understanding of the mystery of our own personhood and our intrinsic connection to the Divine.

Bradley Malkovsky

University of Notre Dame 